\title{
Urban Communities in Medieval South Arabia: A Comparative Reflection ${ }^{1}$
}

\author{
Johann Heiss, Eirik Hovden and Elisabeth Gruber \\ Introduction
}

In this short comparative response to the chapters by Elisabeth Gruber and Oliver Schmitt, we focus on some of the insights that stand out from cooperation on the topic. Some are on a theoretical and methodological level, others on a more empirical one. Most of these insights were developed during fruitful and challenging discussions in the VISCOM-related working group "Urban communities and non-urban sites". Below we will present some of these insights, seen from a South Arabian perspective. In our cooperation leading up to this response we have taken a bottom-up approach, looking closely from different angles at the particular cases we have, as seen through textual sources and physical remains, along with the focus on connectedness between cities and their hinterland.

\section{"City", "Stadt", "Madina”}

Our debates started by trying to define the objects of comparison. This quickly led us to several research debates that on the one hand cannot be ignored, and on the other hand sharpened our interdisciplinary cooperation. The old Weberian concept of "city", as used by several historians of (Central) European history, ${ }^{2}$ is not only highly Eurocentric, but also ideological, with its emphasis on the active participation of townspeople in the nomination of administrative and political positions in medieval European cities. This definition is today

1 The research for this article was funded by the Austrian Science Fund (FWF): F42 Visions of Community the authors would like to thank Maria-Christina Lutter, Fabian Kümmeler and Daniel Mahoney for their comments during the writing process.

2 While most historians recognize that Weber's theories and ideal types need to be criticized, one can still not totally overlook his theories and his impact and reception, especially in studies of the development of cities and the transition from "medieval" to "modern". For example see: Dilcher, "Max Webers 'Stadt", 91-125.

(C) JOHANN HEISS ET AL., 2016 | DOI 10.1163/9789004315693_008

This is an open access chapter distributed under the terms of the Creative Commons Attribution-

Noncommercial-NoDerivatives 3.o Unported (CC-BY-NC-ND 3 .0. Licicense. and Elisabeth Gruber - 9789004315693 
supplemented with outcomesfrom decades of debates. The concept of European "city" is still— to a certain extent—related to the development of the "free citizen" as opposed to the otherwise unfree population in the rural countryside and to the introduction of "city rights" granted by local rulers. In Yemeni studies, it has not been common for historians to think of a system of subjections ${ }^{3}$ in which cities had to appear over time as "enclaves of freedom" with corresponding development of city rights. Rather, a majority of the surrounding population, at least in the Yemeni highlands, were to a large extent seen as tribal members and thus "free" in the first place, something we shall come back to below.

The English term "city" is an apparently easy starting point for a comparison. The term we see much used in our sources from Yemen-denoting what is commonly known as a city or town-is madina. Like "city" (civitas), this term has strong connotations of "civilization" (tamaddun). But the term is not used together with any comparable legal notions of a separation between a free city population and an unfree rural population, or with the notion of "citizenship" as in a community of free equals. Obviously, both the European and "Islamic" sides in the comparison have their old theories and research debates, which in various ways had their own specific ideological undertones.

In pre-Islamic times, the term hajar seems to have meant a "city" or "town" that was central and common to a certain "people" (shacb), ${ }^{4}$ but later, into Islamic times, this term is known more as referring to a tribal market/meeting place. It is a different term than hijra, which is of Islamic origin. ${ }^{5}$ However, in medieval history these two very similar words seem to have partly merged; when a city or village has protection agreements with surrounding tribe(s), the two terms partly merge in the term tahjir, (the act of) granting protection. ${ }^{6}$ A significant difference here would be whether a town or a market is located fully inside the borders of a well-established tribe, or on the borders of several, like Sanaa, which clearly does not belong to just one tribe, although the governorship may be held by one tribe for a certain period. The hijras of the Yemeni highlands described by Hovden in this volume can also be partly seen as "urban communities", being smaller "enclaves" of religious specialization, surrounded by otherwise tribal territory, at least the larger and more important hijras. Looking at terms and emic concepts is a useful first starting point of a

3 What is meant here concerns the concept of feudalism, which has been criticized for a couple of decades, mainly due to the enormous variations in time and space of actual practices. For examples see Cerman, "Villagers"; Rady, Nobility.

4 Beeston, "Sha'b".

5 Madelung, "The Origins of the Yemenite Hijra".

6 Dresch, Tribes, 24-48; Puin, "The Yemeni Hijrah Concept". 
comparison; however, it is ultimately the phenomena behind such terms that we are interested in. We needed a common concept that could be applied to all our cases in Central Europe, Dalmatia and Yemen.

Just as there is a long and complex research tradition on the development of European cites, there is a parallel, still differently configured research tradition on "Islamic cities" in Western academia. The notion of "the Islamic city" is also a theoretical construct that gained some momentum in Western historiography in the colonial period. The Islamic city was seen as a distinct type of city largely formed and influenced by "Islam". However, in more recent years the concept and theory of the Islamic city has received less attention, and arguably rightly so. There is currently a general consensus that cities in the Muslim world were quite diverse and that the impact of "Islam" has always been accompanied by other, more local ideologies, contextual and external factors. In Yemen, cities - and by logical necessity also city culture and institutionsexisted before the advent of Islam. An important question would therefore be to ask how this transition took place. Unfortunately, not much is known about the early phase of Islamization in Yemen, and most research related to the "Islamic city" has been undertaken on cities that were previously under Roman and/or Byzantine influence, something not found in Yemen, a fact that makes the application of such theories to Yemen even more problematic, if not useless. Several strands of the theories of the "Islamic city" also have strong ideological components. ${ }^{7}$ Being aware of these debates, it is most important to point out that we do not intend to compare the "European medieval city" with the "Islamic city" based on these vast debates.

More current debates in European history on medieval cities and urbanism are also most useful for South Arabian historical research. One field that we find particularly interesting is the various degrees of social differentiation within the city and the various ways this was practised and legitimized. The issue of degrees of freedom and social control outside and inside the city is still highly relevant for how we can conceptualize urban communities and how we can understand their development. How is social inequality justified by religious world-views and/or egalitarian tribal visions of community? Is "freedom"

7 The cases and patterns we see from cities in medieval Yemen are much more diverse and more situated in unique Yemeni contexts. It would be unhelpful to first reduce our cases to incidents of "Islamic cities" before comparing them with cases from Central Europe. For a discussion on the concept, see Abu-Lughod, "The Islamic City"; Raymond, "The Spatial Organization of the City", and the volume of which it is part, Jayyusi et. al., eds., The City in the Islamic World. Such debates, however, are most useful, also when studying (Islamic) cities in Yemen. 
a necessary pre-condition for the formation of a city? Is a special personal citystatus and city-identity based on relative freedom necessary for a city to function and develop? These questions still remain important in our cooperation and we shall come back to them shortly below.

\section{Urban Complexities}

An alternative approach to defining the object of comparison, and to structuring the comparison itself is to simply look at a wider cluster of phenomena related to cities and urbanism, revolving around a flexible and open working definition: medium to large settlements, relative density, centrality, and complexity. ${ }^{8}$ Rather than talking about "cities" in a strict categorical sense, we can talk about urban complexity as something different from a comparably sized and more homogenous large village. From there we developed a working comparative matrix consisting of several sub-topics, a work that is still very much in progress. To give an impression how this comparative matrix could work, we present three South Arabian "cases": the cities of Sa'da, Sanaa and Zabid, which we inserted into the matrix, or list of sub-categories. They are all major cities in their regions and highly interrelated with and integrated into their surrounding hinterlands.

\section{Main Functions and Defining Features}

Some cities have one or several clearly specialized functions, for example as a fortress or military centre. Thus the question of the settlement's main functions seemed to be a good starting point for comparison. Other such specializations could be centred on religion, politics, and/or economy. The specialization of a city must of course always be seen in relation to the wider geographical region and in relation to other nearby cities.

Zabid was founded in AD 822 in the centre of the long and narrow coastal plain called Tihama. Before its foundation, there was a string of smaller settlements along the coastal plain, each situated at irrigated pockets where major wadis descend from the highlands onto the plain. Ever since the founding of Zabid, this city became the largest and most important in the region. For many centuries it was the seat of several dynasties ruling this part of Yemen, partly as a sub-unit under the (Sunni) Abbasids, but also more and more independently,

8 Clark, "Introduction". 
a prominent example being the Rasulids and their government. ${ }^{9}$ One can clearly see Zabid as a city of government in the medieval period, with all the side-effects of increased economy, and the resulting centrifugal force on practices related to science, arts and (Sunni) religious learning, that this entailed.

Sa'da and Sanaa are both major cities in fertile basins surrounded by hills in the highlands where the main trade route leads roughly north-south along the mountain plateau. In the late pre-Islamic period the population centres shifted from the eastern fringe of the desert to the highlands, indicating that cities in this region formed before Islam..$^{10}$ Sanaa, and even more Sa'da saw periods were the city was not dominated by a single regional polity for longer periods of time, yet still they remained as important economic and trading centres. Even in pre-Islamic times there was a settlement called Sa'da. ${ }^{11}$ In $814-15$ it was called a madina. The modern town of Sa'da was founded by the first Zaydi imam of Yemen, al-Hādī ilā al-Ḥaqq Yahyā b. al-Ḥusayn, during his reign from AD 897 until 911, possibly on the site of an existing village called al-Ghayl, a couple kilometres north of the old town of Sa'da, which gradually ceased to exist. ${ }^{12}$ Ever since, Sa'da has had a central religious status for Zaydi Muslims.

In the whole medieval period Sanaa was the most important city of the highlands, being a central point for trade and government. Several dynasties and tribal elites in the surrounding districts competed with each other for control over the city. The function as governmental/garrison-centres was important for all of the cities mentioned above, but to varying degree. Governmental activities led to additional income for people in the city; it enhanced the local market and boosted the city economy.

\section{Topography Inside and Surrounding the City}

Here we propose looking at the relation to trade routes, harbours, rivers, strategic military positions, street patterns, planned versus unplanned city quarters, etc.

Comparable to many European towns, the cities Zabid, Sanaa and Sa'da all have a central market area next to the major religious building; the Friday mosque $(a l-j \bar{a} m i)$. All three have city walls. Although there is more uncertainty

$9 \quad$ Croken, "Zabid under the Rasulids of Yemen"; Vallet, L'Arabie marchande. For the Rasulids Zabid was usually the winter capital, in summer they recided in Ta'izz.

10 Brunner, Jemen, 38-41.

11 Niewöhner-Eberhard, Șa'da; Heiss, "Historical Aspects of Șacda".

12 Heiss, "Șacda Revisited". 
about the extent of the city walls in the early period, ${ }^{13}$ in the later medieval period both Sanaa and Zabid had prominent fortresses at the periphery of the city, integrated into the city wall, in Sanaa on the highest point of the city wall on a small hill, similar to many medieval towns in Central Europe. Sanaa and Sa'da are surrounded by hills and mountains and there are several fortresses in strategic places. Zabid had a city wall that was moved several times as the city expanded or retracted. ${ }^{14}$ Zabid was served by several smaller port cities of changing importance and was firmly integrated into and connected with trade routes on the Red Sea and on land. The hinterland of the city consisted of smaller, but significant areas of irrigated agriculture, large areas of grazing lands and rain-fed sorghum agriculture. ${ }^{15}$ Sa'da is situated on the highland route, a main trade- and pilgrim-route connecting the south of the Arabian Peninsula with Mecca and the eastern Mediterranean regions. From Sa'da, connecting routes lead to Najrān to the east (a town and wadi with which close relations developed over time) and to the west, the coast of the Red Sea, especially to a harbour called Sharja (no longer existing). Sa'da was an important centre for iron processing and export. Sometimes tribal groups lived in separate walled-off quarters with their own gates and markets and their own town square, as in Sa'da. The (in most cases weekly) market could be both inside and outside the town wall. ${ }^{16}$

\section{City-Countryside Relations}

It hardly makes sense to analyse a city and its urban communities without looking at various ties and connections with its environs. Relations between urban and rural elites, market dynamics, ownership dynamics, and kinship ties are only a few we could mention here.

Tihama (the Red Sea coastal plain) is considered an area where tribal bonds among the inhabitants are weaker compared to the highland areas surrounding Sanaa and Sa'da. Elites in Zabid could own agricultural land outside and control much of the agricultural surplus in the fertile and productive Tihama. The tribal affiliations imagined as genealogies tend to weaken over time among the inhabitants of towns, a fact that becomes apparent in the way the individual

13 For the city wall of Zabid, see Sadek, "Zabid". For Sanaa, see Lewcock et al., "The Urban Development of Șan'ā”", 129-32.

14 Sadek, "Zabid".

15 Vallet, L'Arabie marchande.

16 Heiss, “Șacda Revisited". 
groups are named. Certain families of high standing in cities remain independent of tribal affiliations. They often specialized in administration and religious/legal services. These and other families inside the city could also own land in the environment of the city, for example orchards and-easily comparable with Vienna-vineyards.

On the late medieval Dalmatian island of Korčula, even members of the urban noble elite were to be found living in small villages on the countryside and sometimes even taking care of their vineyards personally. A clear-cut contrast between urban and rural areas in terms of socio-cultural diversity does not always hold true, as examples from late medieval Dalmatia show. For example, on Korčula, the rural areas were as complex as Dalmatia's urban areas in terms of social and socio-cultural organization. Both the urban and rural areas on Korčula saw a similar population composition of rich and poor, and noble and non-noble people who engaged in various kinds of economic and even political or juridical activities, even though formal political participation in the city's council was restricted to certain members of the urban patriciate. ${ }^{17}$

Also in Yemen, the effects of various ties between urban and rural areas such as kinship, economic and other ties makes the theoretical border between urban and rural more problematic. Not only did people in cities have strong ties to the countryside and vice versa, we also find similar institutions in the countryside as we find in the cities, although to a lesser extent. In this response we have focused on the larger cities, however the picture might have looked more nuanced had the cases been chosen from smaller towns, of which there are many more.

\section{Social Division and Structure Inside the City}

In Sanaa, the medieval city was divided into two major parts, each dominated by a distinct group, the Banū Shihāb, which is the tribe immediately to the south west of Sanaa, and the Abnǟ, of allegedly Persian descent. ${ }^{18}$ Sa'da was also divided into two main parts around $900 \mathrm{AD}$, each dominated by a tribal group, and had been so for a long time. ${ }^{19}$ In addition to these two cases, al-Hamdānī provides a list of cities and settlements that are shared between

\footnotetext{
17 See Schmitt, Korčula sous la domination de Venise au XVe siècle.

18 Lewcock et al., "The Urban Development of Șan ‘̄a”, 124-29.

19 Heiss, "Șacda Revisited".
} 
two competing tribes. ${ }^{20}$ Some families specialized in trades and crafts. Were these specialized groups semi-ethnic groups due to their way of practising endogamy and sustaining their special community? In the case of the Jews, they also had a different religion. These groups show the difficulty of using categorisation such as "ethnic", "tribal" and "religious", when they partly could fit in all of them. The urban complexity in both social organization and culture can be seen in contrast to a more homogenous countryside, where ties to land, territory and tribe were more important.

\section{Legal and Administrative Communities}

A major important issue, and one that is more a hypothesis at this stage, is the focus on the introduction of Islamic law in Yemeni cities. There are mentions of Umayyad and Abbasid governors of Sanaa in the early period of Islam but little is known about the actual government. ${ }^{21}$ From the time of the first Zaydi imams judges ( $q \bar{a} \underline{d} \bar{\imath} \mathrm{pl}$. $q u d \bar{a} t$ ) and governors were appointed over certain areas in the northern highlands, with a basis in regional centres. The highlands of Yemen saw several competing Islamic sects during the medieval period, and local elites appointed judges of their own doctrine. Zaydi, Isma'ili, Sunni and Ibadi judges are mentioned in our sources, the first three as judges of Sanaa for various periods. Producing and authorizing ownership documents is perhaps one of the most important tasks of a judge, but unfortunately we do not have many sources of this type from the medieval period.

One can also make the hypothesis that there must have been some sort of legal community, a community of property owners who respected each others' ownership documents, the authority of the judge and the more or less agreed upon common ownership law. This is not necessarily "Islamic" per se (but therefore also more easily comparable), but these ideas and practices would have been framed in Islamic concepts and in Islamic law. The townspeople seem to have regulated their legal affairs according to the provisions of the customary law ( urf) of the city and of the tribes in the surroundings, but specialists in religious law (sharía) were also available, thus a kind of plurality of legal systems existed where each city had its special features and special mix of law. On this basis there are numerous points on which one could work further and compare with sources and theories from European history.

20 Al-Hamdānī, Sifat, ed. Al-Akwa', 237.

21 For some reflections on this, see Al-'Amrī/Serjeant, "Adminstrative Organisation". 
On Korčula we do not see a strong focus on religious law, but rather a competition between statutory law and (less well-documented) forms of customary law, which tended to be part of conflicts between local inhabitants and the Venetian authorities, as much as it was-traditionally understood-also a conflict between the island's social elites and other inhabitants. The statutory law was composed of documented traditional law and regulations imposed by Venice. $^{22}$

Perhaps the actual imposition of Islamic law in Yemen was not as significant for the local population as the imposition of more "secular" forms of law made and enforced by ruling dynasties, especially related to regulating taxes and privileges of elites. Perhaps we should also focus less on the value-system ("Islam"), which the law was largely formulated in and legitimated by, and rather focus more on the actual types of conflict that the law sought to regulate, inside social groups and between various statuses and groups in society. Here the problem of sources becomes apparent; for the medieval period in Yemen, one mainly has relatively ideal and normative sources (figh, fatwās, administrative treatises) on how the law should be implemented, but very few court documents regarding specific cases.

\section{Religious Infrastructure}

What we certainly can see in our cases from medieval Yemen is the final stages of a presumably slow emergence and development of the usage of Islam as a repertoire in institutions, religion, law and landscape of cities. Clearly, religion plays a central role in providing a framework and a conceptual and legal language for many of the city's institutions. Symbolically and architecturally, religious structures are also prominent parts of the city's landscape; much of "public" infrastructure and its management was framed in religious concepts, most notably the concept of Islamic foundations or endowments (waqf, pl. $a w q \bar{a} f$, in German: Stiftungen) and the treasury of the Muslims (bayt māl al-Muslimin), controlled by the government headed by a sultān on behalf of the caliph or an imam. Mosques were important public spaces where ceremonies of government and political speeches and sermons could take place. Individuals initiated endowments for mosques, schools (madrasa, pl. madāris), public baths (hammām, pl. hammāmāt) or facilities for public water supply. ${ }^{23}$

22 See Schmitt, Korčula sous la domination de Venise au XVe siècle; Foretić, "Borbe”; Ortalli, "Il ruolo degli statuti".

23 See for example Al-'Amrī/Serjeant, "Adminstrative Organisation”, 153; Al-Hadramī, Zabìd, 239 . 
Zabid was the centre of a rich court culture, in which individuals sponsored religious institutions such as a large number of Islamic schools (madrasa, pl. madāris), founded and funded as endowments. ${ }^{24}$

Several of the sub-topics treated above, which together make up a "city", also have parallel aspects of community arising from the cooperation and politics within them, such as in matters of management of common infrastructure (e.g. upkeep of traffic routes, of public water supply and of sanitation systems). A comparative matrix like the one above works best when kept open to change and adjustment in the process of comparison. The friction between the data from the cases and the common categories/theory is a fruitful field were new questions can arise. It may be too artificial to talk about data and theory; however, it is important that we speak the same language and that there is a level in the comparison where categories have to mean more or less the same on both sides of it and have the same validity. A necessarily fuzzy definition built up by such a matrix has proven to function very well to produce new questions. The initially ill-fitted Eurocentric (and for some historians out-dated) definition of city based on the introduction of "civic freedom" is, however, a most important comparative/contrastive point, therefore we shall return to it below.

\section{Urban Autonomy?}

As pointed out above, "feudal" conditions involving local overlordship over unfree peasants as they are known from parts of Europe in the Middle Ages can hardly be claimed to exist in South Arabia, at least not to the same degree and at least not in the tribal highlands. One can also say that this question has not been seen as relevant in the same way as it was in Europe for European historians..$^{25}$ As mentioned above, the question of civic autonomy granted by a lord or an emperor to the city has not been seen as theoretically relevant by historians of South Arabia. The existence of something comparable to a "civic oath" as in Central European cities cannot be confirmed from South Arabian sources; more or less binding oaths (hilf) can rather be found among tribes surrounding the city. We can still learn from the European cases and ask to

\footnotetext{
24 Al-Akwa', al-Madāris al-islāmìyya; al-Haḍramī, Zabìd:Masājiduhā wa-Madārisuhā.

25 The term "feudalism" does not at all have the same (negative?) meaning for researchers on South Arabian history as for many European historians. When applied to medieval South Arabia and compared with tribalism, "feudalism" generates interesting questions that would be otherwise difficult to arrive at, uncovering basic differences and surprising similarities.
} 
what extent there must have been a community inside the city in matters of representation and agreements with surrounding tribes and elites.

In the tribal social order of the highlands, farmers owned their fields individually, and acted as free persons under the protection of the tribe of which they were members, represented vis-a-vis states and other tribes by their tribal lords/shaykhs. This is of course an ideal picture of tribes, an egalitarian model or vision of community, which deserves better elaboration and historical criticism. In practice, tribes were represented by tribal elites at that time called saläțin (pl. of sulțān) or mulūk (pl. of malik, "king") or today's shaykh (pl. shuyükh), some of whom had considerable power also in the tribal highlands. Today, the power of the representatives of the tribal elites can vary greatly from area to area and over time, and this seems also to have been the case in medieval times. Tribal lords might have owned more land than an average tribal member, and there are cases from the present where tribal members work the land of their lords. Tribes could also have individuals, families and whole groups as clients, often with special tasks such as Islamic legal experts and musicians or barbers, specialist groups one might think of as belonging to an "urban" community, who, however, could also live in smaller towns at the countryside, or even travel around.

Individual towns often had protection agreements with surrounding tribes, as was the case with Sanaa and Sa'da. ${ }^{26}$ The protection was usually guaranteed by a tribe as a whole represented by its leadership, its elites, or by several tribes and their tribal elites. Somehow this situation is comparable with conditions in Central Europe at the time, but the situation in the highlands of Yemen seems much more unstable because of the strong competition over the "possession" of a town, which often led to tribal wars and rapid changes concerning the "protection" of a city, especially important cities located on tribal borders. In the period under scrutiny, we do not see an imperial ruler or a dynasty controlling the tribes and the tribal elites in the highlands and thereby securing a lasting peace and stability over generations, as can perhaps can be said to be the case under the Rasulid dynasty ruling Lower Yemen and Zabid.

A major difference between medieval Central Europe and South Arabia seems to be that the majority of the farmers in the environment of a city, at least in the highlands of Yemen, were relatively free and owned their land, as already mentioned. However, similar to central European conditions, a tribe, or rather its "overlordship" granted the city its protection, and tribal elites thus had access to income from local markets and taxation, partly in cooperation with Islamic sects and rulers, such as the Zaydi imams. In both cities, in 
Sanaa and in Sa'da, different tribal groups competed for the overlordship over these cities, and allied themselves with different Islamic denominations and thus situated themselves for or against e.g. the Abbasids and mainstream Sunni orthodoxy. When the term "tribes" (qabila or 'ashira) is used in the medieval South Arabian literature in contexts like this, it is difficult to establish whether an entire tribe or rather a small, elite part of it is meant. This is a field where more research is needed. In some shorter periods in the history of Sanaa there was even a total lack of overlordship, especially in times of fierce competition between tribal groups, ensuing wars and political fragmentation, an example being AD 1006 and the few years before and after. In cases like this the citizens or their leading men obviously had to develop their own ways of governing the city; however, we have no information on how they proceeded. The historians provide just a minimum of information, e.g. Ibn 'Abd al-Majīd (d. 1342-43, writing more than 300 years after the events) stated that Sanaa was without "șultân" for some months in 1006. ${ }^{27}$

\section{Conclusion}

In this comparative analysis we have touched briefly upon a wide range of topics, which all certainly deserve much more thorough elaboration, research and documentation. However, what we have presented will help to understand and conceptualize the different forms of communities inside South Arabian cities and how they were invoked and implemented, also across the city-countryside divide, reaching into otherwise rural, tribal areas. From the very basic descriptions of geographic and practical conditions as starting points it is relatively easy to employ a conceptual language that is valid and useful for understanding cases from Central Europe, Dalmatia and South Arabia. This is due to the geographical and "practical" approach to the topic, which is much easier than to find a common conceptual language for more ideological phenomena, such as emic terms for communities, institutions and norms. However, taking what we have presented, we can use this comparative analysis to make the following hypothesis: there must have been many forms of communities inside South Arabian cities, as well as across the city-countryside divide, reaching into otherwise rural, tribal areas. At this stage it is difficult to say to what extent there was a "civic community" comparable to medieval Central Europe. In times of war, when the cities were surrounded by enemies and under siege, it is difficult not to imagine a single community. Under more normal circumstances,

$27 \quad$ Ibn 'Abd al-Majīd, Bahjat al-zaman, 64. 
visions of community rather followed a wider range of groups, networks, and common activities, partly overlapping and partly diverging, some of which are mentioned above. The question of whether or not there was a civic community is a challenging and interesting one, but one that is difficult to answer due to its Eurocentric origin. Research into the complex forms of community potentially found in family structures, city quarters, legal statuses, religious and ethnic groups, trade and craft production/cooperation and the management of common practical challenges, such as water supply, security and public order is a much more rewarding task. In this way we can ensure that we do not compare only ideological terms, but also the practices behind the terms and the invocation of community by actors and groups with different and conflicting interests.

\section{Bibliography}

Ibn 'Abd al-Majīd, 'Abd al-Bāqī, Tāj al-Dīn, al-Yamānī, Bahjat al-zaman fì tārīkh al-

Yaman, eds. al-Ḥibshī, 'Abd Allāh Muḥammad and Muḥammad Aḥmad al-Sanabānī (Sanaa, 1988).

Al-Akwa', Ismā̄ìl b. 'Alī, al-Madāris al-islāmiyya fì-l-Yaman (Sanaa, Beirut, 1986).

Alfred Felix Landon Beeston, "Sha'b", in Encyclopaedia of Islam, new ed., eds. Peri J.

Bearman, Thierry Bianquis, Clifford Edmund Bosworth, Emeri J. van Donzel and Wolfhart P. Heinrichs (Leiden, 1960-2004), 9:150-52.

Ueli Brunner, Jemen: Vom Weirauch zum Erdöl (Vienna, Cologne, Weimar, 1999).

Markus Cerman, "Villagers and Lords in Eastern Europe" (Basingstoke, 2012).

Peter Clark, "Introduction", in The Oxford Handbook of Cities in World History, ed. Peter Clark (Oxford, 2013).

Barbara Eileen Croken, "Zabid under the Rasulid of Yemen 626-858 AH/1229-1454 AD",

(PhD diss., Harvard University, 1990).

Gerhard Dilcher, "Max Webers 'Stadt' und die historische Stadtforschung der Mediävistik", Historische Zeitschrift 267,1 (1998), 91-125.

Paul Dresch, Tribes, Government, and History in Yemen (Oxford, 1989).

Al-Ḥaḍramī',Abd al-Raḥmān 'Abd 'Allāh, Zabīd: Masājiduhā wa-madārisuhā al-'ilmìyya fìl-tārīkh (Sanaa, Damascus, 200o).

Vinko Foretić, "Borbe između pučana i plemića na Korčuli u 15. i 16. stoljeću”, Sveučilište u Zagrebu - Institut za hrvatsku povijest. Radovi 10 (1977), 249-74.

Al-Hamdānī, al-Ḥasan b. Aḥmad b. Ya'qūb, Șifat jazīrat al-'Arab, ed. Muḥammad b. 'Alī al-Akwa' (Sanaa, 1990).

Johann Heiss, "Historical Aspects of Șa'da, a Yemeni Town", Proceedings of the Seminar of Arabian Studies 17 (1987), 63-80. 
Johann Heiss, “Șa'da revisited”, in Southwest Arabia across History: Essays to the Memory of Walter Dostal, eds. Andre Gingrich and Siegfried Haas (Vienna, 2014), 79-89.

Ronald Lewcock, Paolo Costa, Robert Bertram Serjeant, and Robert Wilson, "The Urban Development of Șan'ā’”, in Șan'ä’ An Arabian Islamic City, eds. Robert Bertram Serjeant and Ronald Lewcock (London, 1983), 122-41.

Janet L. Abu-Lughod, "The Islamic City - Historic Myth, Islamic Essence, and Contemporary Relevance", International Journal of Middle East Studies 19,2 (1987), $155^{-76 .}$

Wilferd Madelung, "The origins of the Yemenite Hijra", in Arabicus Felix: Luminosus Brittanicus: Essays in Honour of A.F.L. Beeston on his Eightieth Birthday, ed. Alan Jones (Reading, 1991), 25-44. Republished in Religious and Ethnic Movements in Medieval Islam (Farnham, Brooksfield, 1992).

Elke Niewöhner-Eberhard, Șa'da: Bauten und Bewohner in einer traditionellen islamischen Stadt, Beihefte zum Tübinger Atlas des Vorderen Orients. Reihe b. Geisteswissenschaften 64 (Wiesbaden, 1985).

Gherardo Ortalli, "Il ruolo degli statuti tra autonomie e dipendenze: Curzola e il dominio veneziano", Rivista storica italiana 98 (1986), 195-220.

Gerd R. Puin, "The Yemeni Hijrah Concept of Tribal Protection" in Land Tenure and Social Transformation in the Middle East, ed. Tarif Khalidi (Beirut, 1984), 483-94.

Martyn C. Rady, Nobility, Land and Service in Medieval Hungary, (Basingstoke, 2010).

Andre Raymond, "The Spatial Organization of the City", in The City in the Islamic World, eds. Salma K. Jayyusi, Renata Holod, Attilio Petruccioli and André Raymond (Leiden, 2008).

Noha Sadek, "Zabid: The Round City of Yemen", in Studies in Honour of Professor G. Rex Smith, eds. John F. Healey and Venetia Porter (Oxford, 2002).

Oliver Jens Schmitt, Korčula sous la domination de Venise au $X V^{e}$ siècle. Pouvoir, économie et vie quotidienne dans une île dalmate au Moyen Âge tardif, Les Conférences du Collège de France (Paris, 2011). <http://books.openedition.org/cdf/1501>

Robert Bertram Serjeant, "Chapter 5: Șan'ā’ the Protected Hijra”, in Șan'ā’: An Arabian Islamic City, eds. Robert Bertram Serjeant and Ronald Lewcock (London, 1983), 39-43.

Eric Vallet, L'Arabie marchande: Etat et commerce sous les sultans rasûlides du Yémen (626-858/1229-1454) (Paris, 2010). 